\title{
Landslide susceptibility assessment of the Chure Khola Catchment area of the Siwalik region, Central Nepal
}

\author{
*Prakash Gyawali1 and Naresh Kazi Tamrakar² \\ ${ }^{1}$ Department of Irrigation, Lalitpur, Nepal \\ ${ }^{2}$ Central Department of Geology, Tribhuvan University, Kirtipur, Kathmandu, Nepal \\ *Corresponding author: gyawali317@gmail.com
}

\begin{abstract}
Landslide susceptibility analysis is carried out in the Chure Khola Catchment, between Amlekhganj and the Churia Mai Range of the Bara District, covering area of 20 sq. km. The catchment lies in the Siwalik Hills composing the Siwalik Group of rocks of Middle Miocene to Early Pleistocene age. Owing to the week and fragile geology, the Siwalik Hills are prone to the gully erosion, shallow landslide and debris flow, during the heavy rain storms in monsoon seasons. In the present study, landslide susceptibility assessment was carried out using two methods, rapid field-based assessment and statistical index methods. For the susceptibility mapping of the river bank slopes, field- based method was used. The seven parameters such as slope angle, slope material, reduction to groundwater, effect of drainage, effect of past failure, effect of vegetation cover and effect of land use were used to calculate the factor of safety in the field. The slope areas were classified as highly susceptible (FS $<0.7)$, susceptible $(0.7<\mathrm{FS}<1)$, marginally stable $(1<\mathrm{FS}<1.2)$ and stable (FS $>1.2)$ categories, and finally, a susceptibility map was prepared. For the total 4.179 sq. km area where rapid field-based assessment was carried out, the areas covered by highly susceptible, susceptible, marginally stable and stable zones are respectively, $21.56 \%, 22.11 \%, 17.37 \%$ and $38.95 \%$. Among the highly susceptible and susceptible zones identified, $71 \%$ sites have experienced recent slope failures. Landslide susceptibility mapping of the whole catchment area was prepared using statistical index method, and considering seven causative parameters such as elevation, slope, slope aspect, curvature, river proximity, stream density and lithology, which were determined and prepared from DEM using Arc GIS. Eighty percent landslides were used as the training sample for the spatial analysis, whereas $20 \%$ landslides were used for the validation of the study. The landslide susceptibility map exhibits the areas covered by very high, high, moderate, low and very low susceptibility zones are $47.18 \%, 25.28 \%, 19.77 \%, 3.60 \%$ and $4.16 \%$, respectively. Validity of the study was determined using Riemann Sums method. Success Rate Curve shows that $78.04 \%$ of the areas lie under the curve. Evaluating susceptibility in small watershed is important to mitigate shallow landslide related problems and in rehabilitating forest areas in the Churiya Hills of Nepal.
\end{abstract}

Keywords: Landslide susceptibility, Siwaliks, Churiya Hills, Statistical Index Method

Paper Received: 28 Mar 2018

Paper Accepted: 3rd June 2018

\section{INTRODUCTION}

Landslide is generally used to denote the downward and outward movement of slope forming materials along surfaces of separation (Varnes, 1978). Landslide in which the sliding surface is located within the mantle or (upto 3-10 m) is called a shallow landslide. Landslides are natural phenomena which occur under the favorable terrain conditions and are usually triggered by heavy rainfall, human activities and earthquake. Landslides occur due to combination of trigger mechanisms and susceptibility factors such as fragile and complex geology, steep slopes, rugged topography, variable climatic and microclimatic conditions, rainfall, earthquake and vegetation degradation (Gerrard and Gardner, 2002; Hasegawa et al., 2009). The Siwaliks Hills are vulnerable to landslides because of fragile geology, weak lithology and tectonics (Tamrakar et al., 2002; Tamrakar and Yokota, 2008). Landslides cause loss of lives and property each year during the monsoon season in hilly regions of Nepal where geology is very fragile.
Landslide susceptibility is defined as a function of the degree of the inherent stability of the slope together with the presence and activity of causative factors capable of reducing the excess strength and ultimately triggering movement (Crozier and Glade, 2005). The identification of causative factors is the basis of many methods of susceptibility/stability assessment. The factors may be dynamic, or passive and may also be considered in terms of the roles they perform in destabilizing a slope (Crozier, 1986). Mostly, heuristic approach, statistical approach and deterministic approach are used for landslide susceptibility mapping. Among these techniques, Sikrikar et al. (1998), Dhakal et al. (1999), Dangol and Ulak (2002), Dhital et al. (2005) and Dahal et al. (2008) used the statistical analysis methods for the landslide susceptibility mapping in Nepal. Lee and Evangelista (2006) used artificial neural network to prepare landslide susceptibility map.

In the bivariate models each individual thematic map in terms of landslide distribution is considered and implemented 
in GIS (Van Westen, 1997). The statistical index method is a bivariate statistical analysis as introduced by Van Westen (1997) for landslide susceptibility analysis. In the beginning, the statistical index method was called landslide index method. However, researcher further used this statistical bivariate method in the name of statistical index method. Statistical approach is an indirect susceptibility mapping technique which involves statistical determination of the combinations of variables that have led to landslide occurrence in the past. All possible intrinsic variables are entered into a GIS and crossed for their analysis with a landslide inventory map. In most of the cases, the statistical approach to landslide hazard mapping is either bivariate or multivariate.

Landslides and gully erosion are the sources of materials for the debris flow. Debris flows also scour the banks of the river channels. Landslides and debris flows cause the extensive damage of landmass property and occasionally the lives. These problems are quite frequent in the Siwalik region. Therefore, it is necessary to assess and manage the areas, which are susceptible to landslide, to mitigate any associated damage. A large volume of sediments from the Siwalik Hills is carried away as a form of debris flow and flashflood. Studying slope sediments properties, and landslide types, mechanism, causes and distribution help to evaluate susceptibility of landslide in a small watershed. Such study is important to mitigating shallow landslide related problems and in rehabilitating forest areas in the Churiya Hill regions of Nepal.

\section{STUDY AREA}

The study area constitutes a hilly terrain of the Sub Himalaya (Siwalik) along the Chure Khola from Amlekhganj to the Churiya Range (Fig. 1). The altitude ranges from $345 \mathrm{~m}$ at the Amlekhganj to $807 \mathrm{~m}$ at the Churiya Range and covers the 20 sq. $\mathrm{km}$ area. The maximum and minimum temperatures of the area are $38^{\circ} \mathrm{C}$ and $6^{\circ} \mathrm{C}$, respectively. The area experiences an average yearly rainfall of $2160 \mathrm{~mm}$, and a sub-tropical climate. The drainage pattern of the study area is dendritic. The north to south flowing Chure Khola is the trunk river and is contributed by the Bhedi Khola from the eastern portion. These streams are originated from the southern face of the Churiya Range and are seasonal.

\section{GEOLOGICAL SETTING}

The study area belongs to the Siwalik Group (the Middle Siwalik and the Upper Siwalik) of Central Nepal. The Chure Khola watershed area consists of three lithological units namely the Amlekhganj Formation, the Chure Khola Formation and the Churia Mai Formation (Sah et al., 1994). The Amlekhganj Formation is characterized by multistoreyed, coarse-grained, 'salt and pepper' sandstone to pebbly sandstone interlayered with greenish grey mudstone. The Chure Khola Formation consists of loosely consolidated and matrix- to clast-supported pebble to cobble conglomerate. The upper part of this formation is characterized by calcareous cemented conglomerate beds.

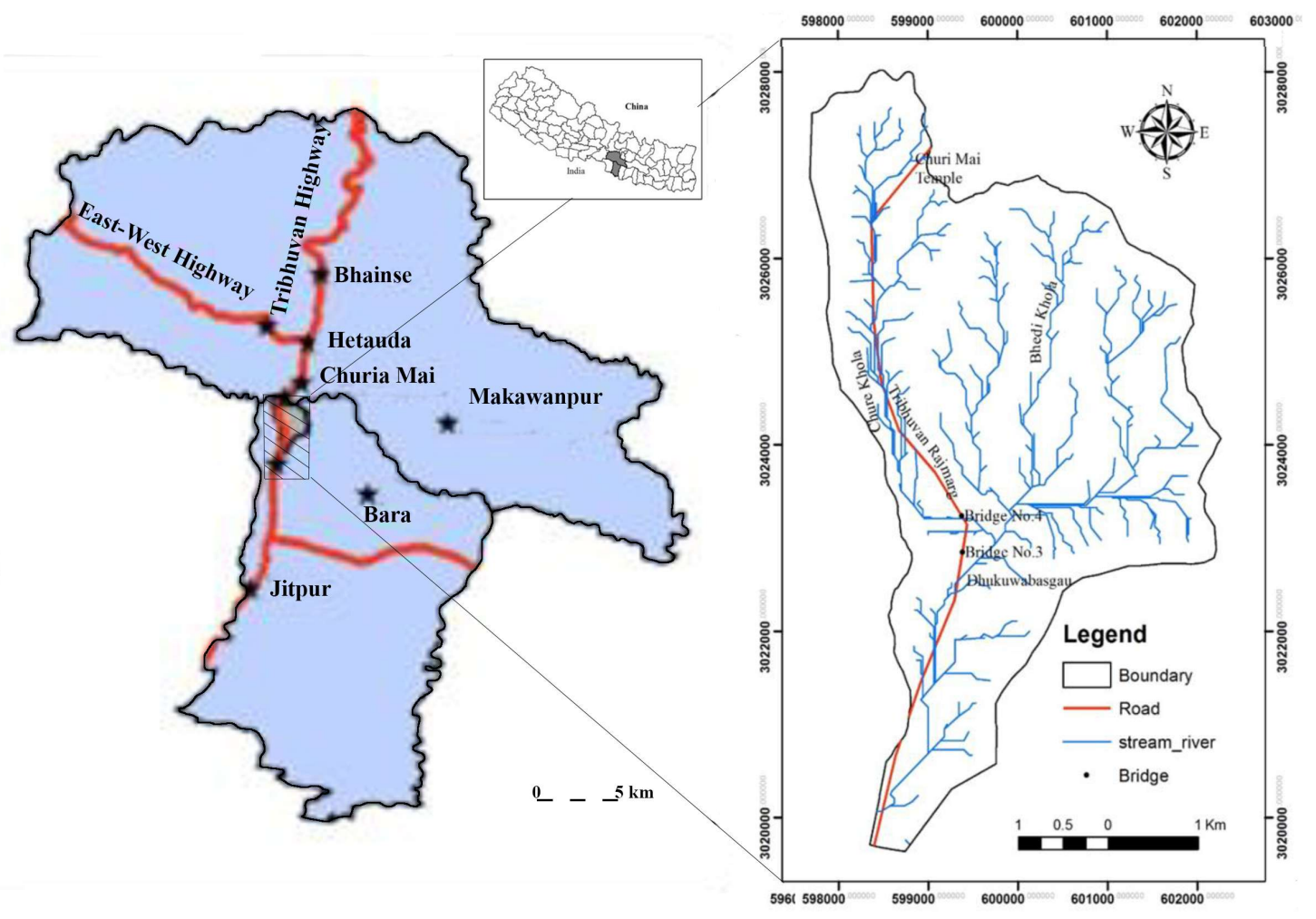

Fig. 1: Study Area 
The Churia Mai Formation consists of loosely consolidated and matrix-supported pebble to boulder conglomerate having poorly sorted and randomly oriented clasts.

\section{METHODOLOGY}

In this study, landslide susceptibility mapping of the river bank slope of the Chure Khola in central Nepal Churia region was prepared using the field-based method after Peckley and Bagtang (2010) and bivariate (statistical-index) method after Van Westen (1997).

In the field-based susceptibility analysis, factor of safety was calculated using various parameters. The susceptible areas were identified and delineated in the field. The parameters used to calculate the factor of safety were slope angle, slope materials, reduction to ground water, effect of reduction drainage, effect of past failure, effect for vegetation and land use (Fig. 2). The factor of safety (Fs) was determined by using the following equation after Peckley and Bagtang (2010):

$$
\mathrm{F}_{\mathrm{s}}=\frac{[\mathrm{v} \text { Factor } * \text { f Factor }(\text { S Rating }-\mathrm{s} \text { Red }-\mathrm{d} \text { Red })]}{[\alpha \text { Rating } * \text { I Factor }]}
$$

where,

Alpha Rating = slope angle, $\mathrm{S}$ Rating = slope material, $\mathrm{s}$ Red $=$ reduction due to ground water, $\mathrm{d}$ Red $=$ effect of drainage

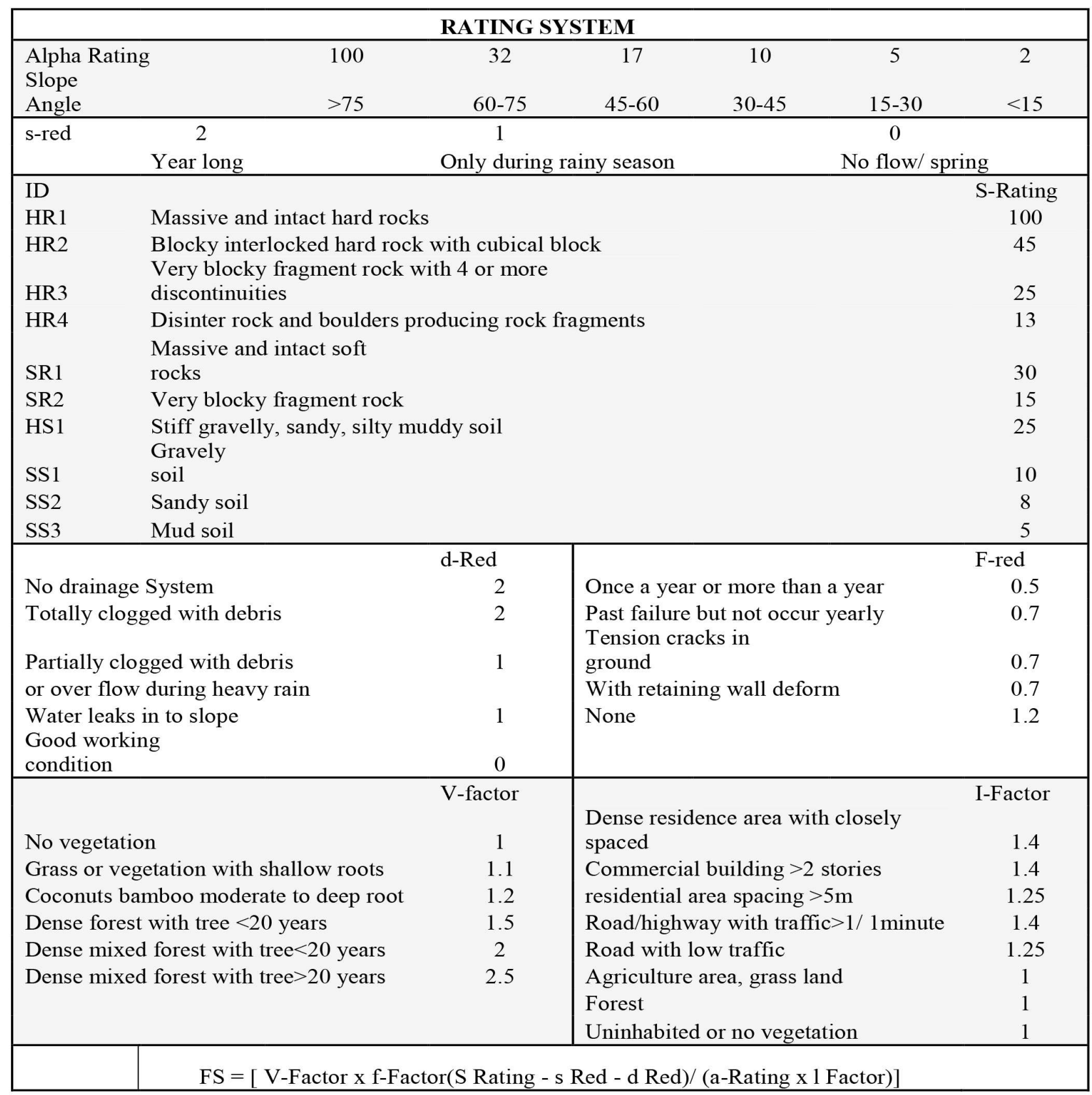

Fig. 2: Rating system for field-based susceptibility mapping (after Peckley and Bagtang, 2010) 
Table 1: Factor of safety for landslide susceptibility zonation

\begin{tabular}{ll}
\hline Landslide susceptibility & Factor of Safety (Fs) \\
\hline Stable & Fs $>1.2$ \\
Marginally Stable & $1.0<$ Fs $<1.2$ \\
Susceptible & $0.7<$ Fs $<1.0$ \\
Highly Susceptible & Fs $<0.7$ \\
\hline
\end{tabular}

or surface runoff, f Factor $=$ effect of past and ongoing slope movement, $\mathrm{v}$ Factor $=$ effect of vegetation covering, and I Factor $=$ effect of land use. The landslide susceptibility zonation was based on the factor of safety (Table 1).

Various methods have been developed and used for landslide susceptibility mapping in watershed-scale. In this study, statistical index-based method was used. This method is based upon the following equation (Van Westen, 1997b),

$$
\begin{aligned}
\mathrm{W}_{\mathrm{ij}} & =\ln \left[\mathrm{f}_{\mathrm{ij}} / \mathrm{f}\right]=\ln \left[\mathrm{A}^{*}{ }_{\mathrm{ij}} / \mathrm{A}_{\mathrm{ij}} * \mathrm{~A} / \mathrm{A}^{*}\right] \\
& =\ln \left[\mathrm{A}_{\mathrm{ij}} / \mathrm{A}^{*} \mathrm{~A} / \mathrm{A}_{\mathrm{ij}}\right]
\end{aligned}
$$

where, $\mathrm{W}_{\mathrm{ij}}$ - the weight given to a certain class $\mathrm{i}$ of parameter $\mathrm{j}$,

$\mathrm{f}_{\mathrm{ij}}=$ landslide density within the class $\mathrm{i}$ of parameter $\mathrm{j}$, $\mathrm{f}=$ landslide density within the entire map,

$A^{*}{ }_{i j}=$ area of landslides in a certain class $i$ of parameter $j$,

$A_{i j}=$ area of a certain class $\mathrm{i}$ of parameter $\mathrm{j}$,

$A=$ total area of the entire map, and

$\mathrm{A}^{*}=$ total area of landslides in the entire map.

For the preparation of the susceptibility map, a landslide inventory map, geological map, aspect map, slope angle map, and distance from drainage were prepared. Using these thematic maps like slope, aspect, curvature, elevation, stream density, river proximity and geology, the susceptibility analysis was carried out applying bivariate (statistical-index) methods (Van Westen, 1997). These data were integrated in Arc GIS and weighted for each class determined from the statistical index method (Van Westen, 1997). The final susceptible zonation map was categorized into very low, low, moderate, high and very high susceptibility classes based on landslide susceptibility index value (LSI).

Percentage of landslide occurrence in any susceptible zone is termed success rate. This is also a way to validate a susceptibility map. The cumulative percentage of landslide occurrences in the susceptibility zones ordered from high to low were plotted against the cumulative percentage of area of the susceptibility zone. The resulting curve is called success rate curve. Success rate curves were prepared by calculating an
AUC value by using Riemann Sums methods as below:

$$
\mathrm{AUC}=[(\mathrm{b} 1+\mathrm{b} 2) / 2] .(\mathrm{A} 2-\mathrm{A} 1)
$$

where, b1 and b2 are cumulative percentage of area of landslide within given LSI value, whereas A1 and A2 are the cumulative percentage of the study area within given LSI value.

\section{RESULT AND DISCUSSION}

\section{Field based susceptibility mapping}

According to factor of safety, river bank slopes were summarized into four zones, i.e., highly susceptible, susceptible, marginally stable and stable. The results of landslide susceptibility analysis, factor of safety and susceptibility zones are tabulated for 74 locations assessed (Fig. 3; Table 2).

Thirty-three sites lie in highly susceptible zone, 12 sites in susceptible zone, 3 sites in marginally stable zone and 26 sites in stable zones. The slope area covers 4.179 sq. $\mathrm{km}$ area

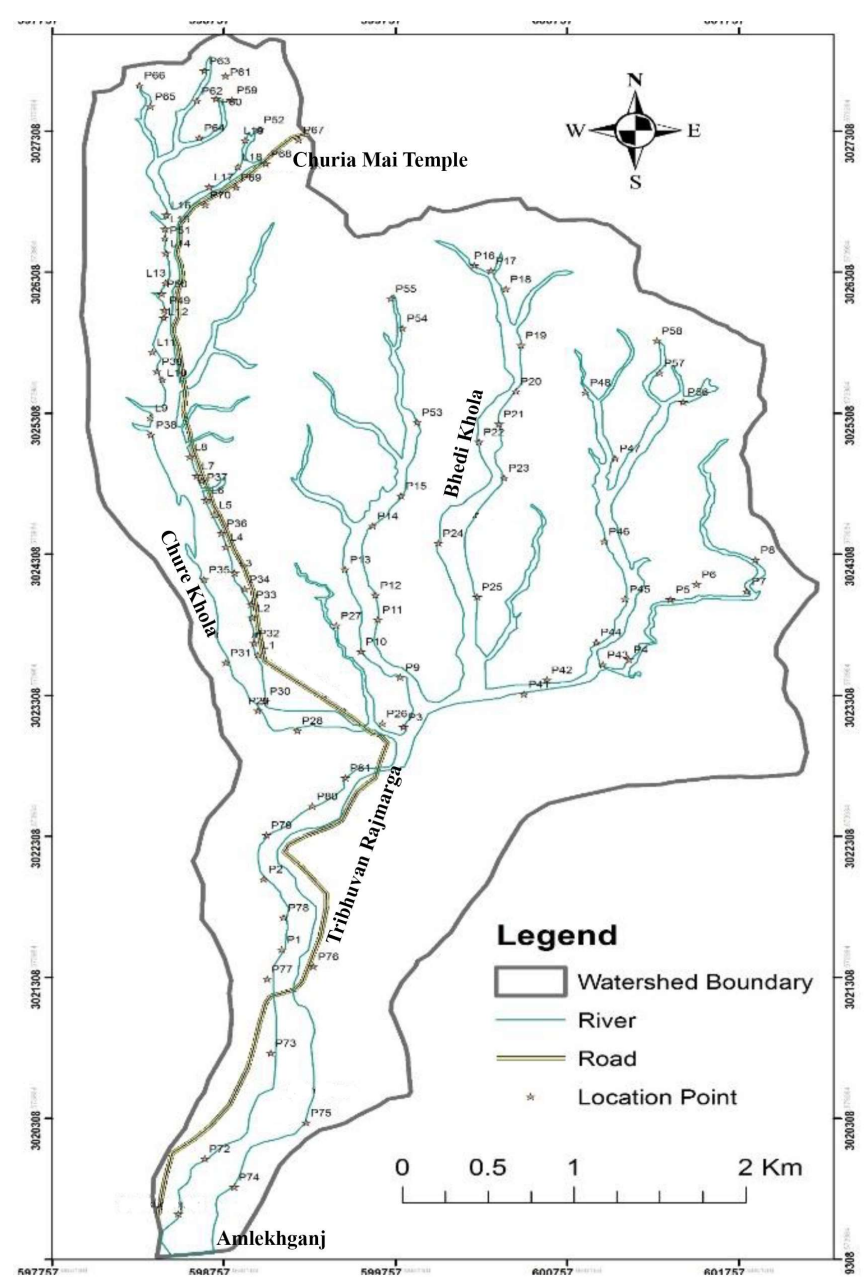

Fig. 3: Location sites of the observation for susceptibility mapping 
Table 2: Summarized table of factor of safety for field based susceptibility mapping

\begin{tabular}{|c|c|c|c|c|c|c|c|c|c|c|}
\hline S. N & Location & a-Rating & s Red & S Rating & d-Red & V Factor & f- Factor & I Factor & $\mathrm{F}_{\mathrm{s}}$ & Susceptibility \\
\hline 1 & L1 & 100 & 1 & 25 & 2 & 1.1 & 0.7 & 1.4 & 0.1489 & Highly Susceptible \\
\hline 2 & $\mathrm{~L} 2$ & 100 & 1 & 25 & 2 & 1.1 & 0.5 & 1.4 & 0.106 & Highly Susceptible \\
\hline 3 & L3 & 32 & 1 & 25 & 2 & 1.1 & 0.5 & 1 & 0.6328 & Highly Susceptible \\
\hline 4 & L4(a) & 17 & 1 & 25 & 2 & 1.1 & 0.7 & 1.4 & 0.87 & Susceptible \\
\hline 5 & $\mathrm{~L} 4(\mathrm{~b})$ & 17 & 1 & 25 & 2 & 1.1 & 0.7 & 1 & 1.22 & Stable \\
\hline 6 & L5 & 32 & 1 & 25 & 2 & 1.1 & 0.5 & 1.4 & 0.3 & Highly Susceptible \\
\hline 7 & L6 & 10 & 1 & 25 & 2 & 1.5 & 0.7 & 1 & 1.223 & Stable \\
\hline 8 & L7 & 10 & 1 & 25 & 2 & 1.1 & 0.7 & 1 & 1.735 & Stable \\
\hline 9 & L8 & 32 & 1 & 25 & 2 & 1.1 & 0.5 & 1 & 0.46 & Highly Susceptible \\
\hline 10 & L9 & 100 & 1 & 25 & 2 & 1.1 & 0.5 & 1 & 0.1485 & Highly Susceptible \\
\hline 11 & L10 & 100 & 1 & 25 & 2 & 1.1 & 0.5 & 1.4 & 0.106 & Highly Susceptible \\
\hline 12 & L11 & 17 & 1 & 25 & 2 & 1.1 & 0.5 & 1 & 0.873 & Susceptible \\
\hline 13 & L12 & 32 & 1 & 25 & 2 & 1.5 & 0.7 & 1.1 & 0.464 & Highly Susceptible \\
\hline 14 & L13 & 17 & 1 & 25 & 2 & 1.1 & 0.7 & 1.4 & 1.191 & Stable \\
\hline 15 & L14 & 17 & 1 & 25 & 2 & 1.1 & 0.7 & 1 & 0.873 & Susceptible \\
\hline 16 & L15 & 100 & 1 & 25 & 2 & 1.1 & 0.5 & 1 & 0.1485 & Highly Susceptible \\
\hline 17 & L16 & 32 & 1 & 25 & 2 & 1.1 & 0.7 & 1 & 0.7146 & Susceptible \\
\hline 18 & L17 & 32 & 1 & 25 & 1 & 1.1 & 0.7 & 1 & 0.708 & Susceptible \\
\hline 19 & L18 & 17 & 1 & 25 & 2 & 1.1 & 0.5 & 1 & 0.874 & Susceptible \\
\hline 20 & L19 & 17 & 1 & 25 & 2 & 1.1 & 0.5 & 1 & 0.874 & Susceptible \\
\hline 21 & $\mathrm{P} 1$ & 5 & 0 & 15 & 2 & 1.1 & 1.2 & 1 & 3.4 & Stable \\
\hline 22 & $\mathrm{P} 2$ & 5 & 0 & 15 & 2 & 1.1 & 1.2 & 1 & 3.4 & Stable \\
\hline 23 & P3 & 32 & 1 & 30 & 2 & 1.1 & 0.7 & 1 & 0.7 & Susceptible \\
\hline 24 & P10 & 5 & 1 & 25 & 2 & 1.5 & 1.2 & 1 & 1.58 & Stable \\
\hline 25 & P11 & 17 & 1 & 25 & 2 & 1 & 0.5 & 1 & 0.53 & Highly Susceptible \\
\hline 26 & $\mathrm{P} 12$ & 32 & 1 & 25 & 2 & 1.1 & 0.7 & 1 & 0.76 & Susceptible \\
\hline 27 & P13 & 32 & 1 & 25 & 2 & 1.1 & 0.5 & 1 & 0.38 & Highly Susceptible \\
\hline 28 & P16 & 32 & 0 & 25 & 2 & 1.5 & 0.7 & 1.1 & 0.38 & Highly Susceptible \\
\hline 29 & P17 & 17 & 0 & 25 & 2 & 1 & 0.5 & 1 & 0.34 & Highly Susceptible \\
\hline 30 & P18 & 17 & 1 & 25 & 2 & 1.1 & 0.7 & 1 & 0.87 & Susceptible \\
\hline 31 & P19 & 32 & 1 & 25 & 2 & 1 & 0.5 & 1 & 0.38 & Highly Susceptible \\
\hline 32 & P20 & 17 & 0 & 25 & 2 & 1 & 0.5 & 1.1 & 0.38 & Highly Susceptible \\
\hline 33 & P24 & 32 & 0 & 25 & 2 & 1 & 0.5 & 1 & 0.34 & Highly Susceptible \\
\hline 34 & P27 & 17 & 1 & 25 & 2 & 2 & 1.2 & 1 & 5.4 & Stable \\
\hline 35 & P29 & 17 & 0 & 25 & 2 & 1.1 & 0.7 & 1 & 1.32 & Stable \\
\hline 36 & P30 & 32 & 0 & 25 & 2 & 1.1 & 0.5 & 1 & 0.52 & Highly Susceptible \\
\hline 37 & P31 & 17 & 0 & 25 & 2 & 1 & 0.5 & 1 & 0.68 & Highly Susceptible \\
\hline
\end{tabular}


Table 2: continued

\begin{tabular}{|c|c|c|c|c|c|c|c|c|c|c|}
\hline S. N & Location & a-Rating & s Red & S Rating & d-Red & V Factor & f- Factor & I Factor & $F_{s}$ & Susceptibility \\
\hline 38 & P32 & 32 & 1 & 25 & 2 & 2 & 0.7 & 1 & 1.06 & Marginally stable \\
\hline 39 & P33 & 10 & 0 & 25 & 2 & 2 & 0.7 & 1 & 2.3 & Stable \\
\hline 40 & P35 & 17 & 0 & 25 & 2 & 1.1 & 0.7 & 1 & 0.51 & Highly Susceptible \\
\hline 41 & P36 & 17 & 0 & 25 & 2 & 1.1 & 1.2 & 1.4 & 2.07 & Stable \\
\hline 42 & P38 & 100 & 0 & 25 & 2 & 1 & 0.5 & 1 & 0.2 & Highly Susceptible \\
\hline 43 & P39 & 32 & 0 & 25 & 2 & 1.1 & 0.5 & 1 & 0.26 & Highly Susceptible \\
\hline 44 & $\mathrm{P} 40$ & 32 & 0 & 25 & 2 & 1 & 0.5 & 1 & 0.72 & Susceptible \\
\hline 45 & P41 & 10 & 0 & 25 & 2 & 2 & 1.2 & 1 & 6.44 & Stable \\
\hline 46 & $\mathrm{P} 42$ & 10 & 1 & 25 & 2 & 2 & 0.7 & 1 & 2.31 & Stable \\
\hline 47 & P43(a) & 32 & 0 & 25 & 2 & 1.1 & 0.7 & 1 & 0.83 & Susceptible \\
\hline 48 & P43(b) & 17 & 0 & 25 & 2 & 2 & 0.7 & 1 & 0.18 & Highly Susceptible \\
\hline 49 & P44 & 17 & 0 & 25 & 2 & 1.1 & 0.5 & 1 & 3.22 & Stable \\
\hline 50 & P45 & 32 & 1 & 25 & 2 & 1 & 0.5 & 1 & 1.89 & Stable \\
\hline 51 & P46 & 32 & 0 & 25 & 2 & 1.1 & 0.7 & 1 & 0.55 & Highly Susceptible \\
\hline 52 & P47 & 100 & 0 & 25 & 2 & 1 & 1.2 & 1 & 0.18 & Highly Susceptible \\
\hline 53 & P48 & 10 & 0 & 25 & 2 & 2 & 0.7 & 1 & 3.22 & Stable \\
\hline 54 & P49 & 17 & 0 & 25 & 2 & 2 & 0.7 & 1 & 1.89 & Stable \\
\hline 55 & $\mathrm{P} 50$ & 32 & 0 & 25 & 2 & 1.1 & 0.7 & 1 & 0.55 & Highly Susceptible \\
\hline 56 & P51 & 5 & 0 & 25 & 2 & 2 & 1.2 & 1.1 & 6.7 & Stable \\
\hline 57 & P52 & 17 & 0 & 25 & 2 & 1.1 & 0.7 & 1 & 1.04 & Stable \\
\hline 58 & P53 & 32 & 0 & 25 & 2 & 1.1 & 0.5 & 1 & 0.54 & Highly Susceptible \\
\hline 59 & P54 & 17 & 0 & 25 & 2 & 1.1 & 0.7 & 1 & 0.67 & Highly Susceptible \\
\hline 60 & $\mathrm{P} 67$ & 32 & 0 & 25 & 2 & 1.1 & 0.5 & 1 & 0.4 & Highly Susceptible \\
\hline 61 & P68 & 32 & 0 & 25 & 2 & 1.1 & 0.5 & 1 & 1.35 & Stable \\
\hline 62 & P69 & 10 & 0 & 25 & 2 & 1.1 & 1.2 & 1.25 & 0.99 & Susceptible \\
\hline 63 & $\mathrm{P} 70$ & 17 & 0 & 25 & 2 & 1.1 & 0.7 & 1 & 5.28 & Stable \\
\hline 64 & P71 & 2 & 0 & 10 & 2 & 1.1 & 1.2 & 1 & 5.28 & Stable \\
\hline 65 & $\mathrm{P} 72$ & 2 & 1 & 10 & 2 & 1.1 & 1.2 & 1 & 5.28 & Stable \\
\hline 66 & $\mathrm{P} 73$ & 2 & 0 & 10 & 2 & 1.1 & 1.2 & 1 & 5.28 & Stable \\
\hline 67 & P74 & 2 & 0 & 10 & 2 & 1.1 & 1.2 & 1 & 0.4 & Highly Susceptible \\
\hline 68 & P75 & 17 & 1 & 15 & 1 & 1.1 & 0.5 & 1 & 3.19 & Stable \\
\hline 69 & P76 & 5 & 1 & 15 & 1 & 1.1 & 1.2 & 1 & 3.19 & Stable \\
\hline 70 & P 77 & 5 & 0 & 15 & 2 & 1.1 & 1.2 & 1 & 5 & Stable \\
\hline 71 & P78 & 2 & 1 & 15 & 2 & 1.1 & 0.7 & 1 & 0.23 & Highly susceptible \\
\hline 72 & P 79 & 32 & 0 & 15 & 1 & 1 & 0.5 & 1 & 0.23 & Highly Susceptible \\
\hline 73 & P 80 & 32 & 0 & 15 & 2 & 1 & 0.5 & 1 & 0.23 & Highly Susceptible \\
\hline 74 & P81 & 32 & 0 & 15 & 2 & 1 & 0.5 & 1 & 0.23 & Highly Susceptible \\
\hline
\end{tabular}


of river bank slope of the Chure Khola and the Bhedi Khola (Fig. 4). Landslide susceptibility map shows that 0.901 sq. km $(21.56 \%)$ area fall in highly susceptible zone, 0.924 sq. km $(22.11 \%)$ in susceptible zone, 0.726 sq. $\mathrm{km}(17.37 \%)$ in marginally stable zone and 1.28 sq. $\mathrm{km}(38.95 \%)$ in stable zone (Fig. 4; Table 3). Most of the stable area (more than $60 \%$ of it) lies in the plain area near Amlekhganj. Most of the slope area of the Chure Khola Formation and the Churia Mai Formation lies in the susceptible and highly susceptible zones.
For the validity of the study, it was cross checked to know whether the observation sites that lie in the susceptible and highly susceptible zone have undergone recent failure or not. None of the sites with factor of safety above 1 failed and almost $71 \%$ of the sites with the factor of safety below 1 have failed (Table 3). For those with the factor of safety below 0.7 , the percentage of failure is $84 \%$ as only recent failure have been included for this analysis. If we take some old failures, then all sites with Fs below 1 lie in failure and very few surveyed sites

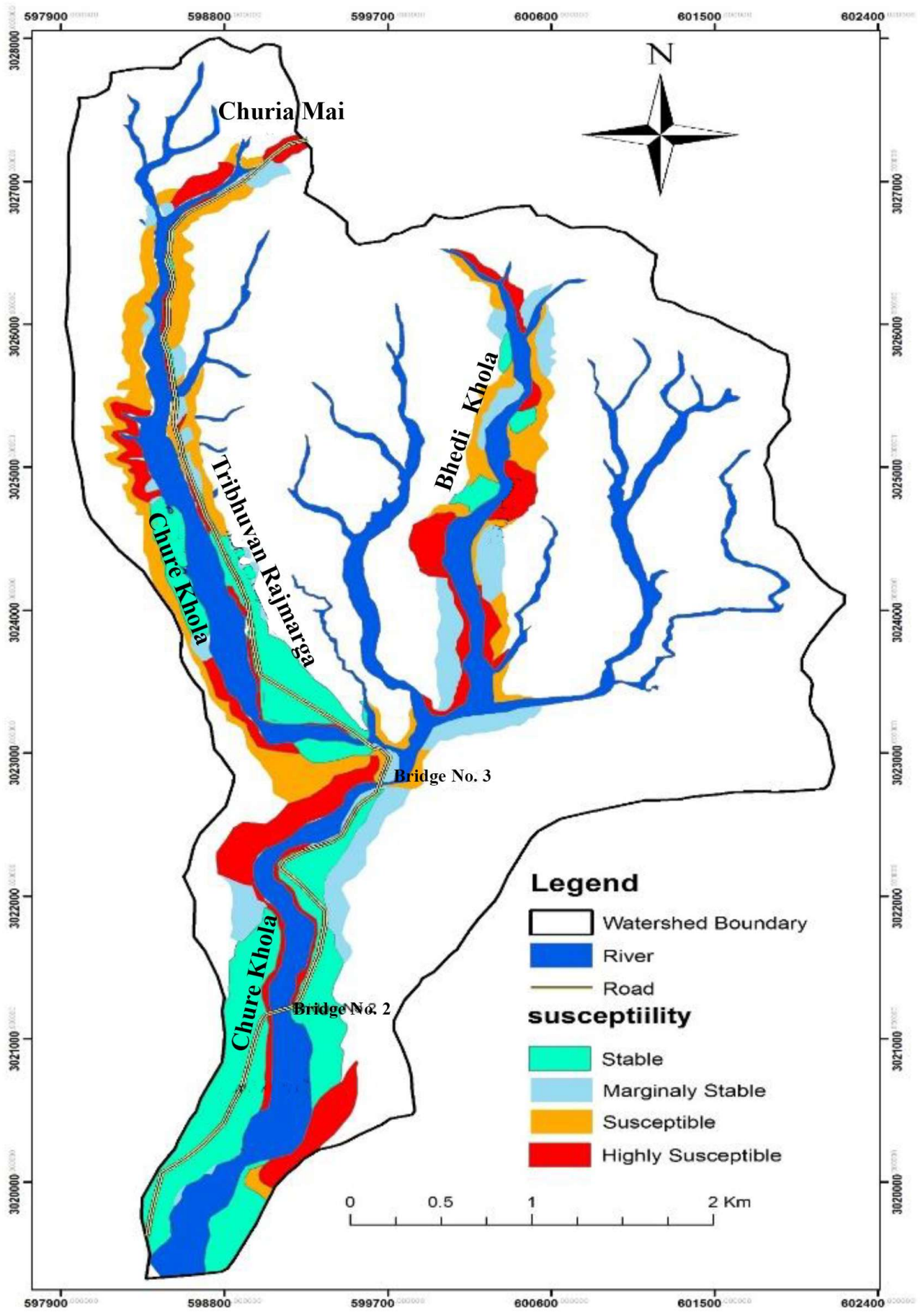

Fig. 4: Susceptibility map of the river bank slope 
Table 3: validation chart representing relation of observed site and failure condition

\begin{tabular}{lccccc}
\hline Factor of safety (Fs) & $\begin{array}{c}\text { No of sites } \\
\text { Surveyed }\end{array}$ & $\begin{array}{c}\text { No of site } \\
\text { that Fails }\end{array}$ & $\begin{array}{c}\text { Percentage } \\
\text { failure }\end{array}$ & $\begin{array}{c}\text { Past } \\
\text { failure }\end{array}$ & $\begin{array}{c}\text { \% including } \\
\text { Past failure }\end{array}$ \\
\hline Fs $<0.7$ : Highly susceptible & 33 & 28 & 84 & 5 & 100 \\
$0.7<$ Fs $<1.0$ : Susceptible & 12 & 4 & 33.33 & 8 & 100 \\
$1<$ Fs $<1.2$ : Marginally stable & 3 & 0 & 0 & 3 & \\
Fs $>1.2$ : Stable & 26 & 0 & 0 & 8 & \\
Total & 74 & 32 & 71 & 24 & \\
\hline
\end{tabular}

with Fs above 1 lie in the past failure.

\section{Landslide Susceptibility Analysis Using Bivariate Statistical Methods}

From the field observation, 152 landslides were identified. Only the $80 \%$ of total landslide were used for the spatial analysis as a training sample where as $20 \%$ landslides were used to determine the succession rate. The landslide inventory map was prepared with $80 \%$ training landslides and 20\% landslide (Fig. 5).

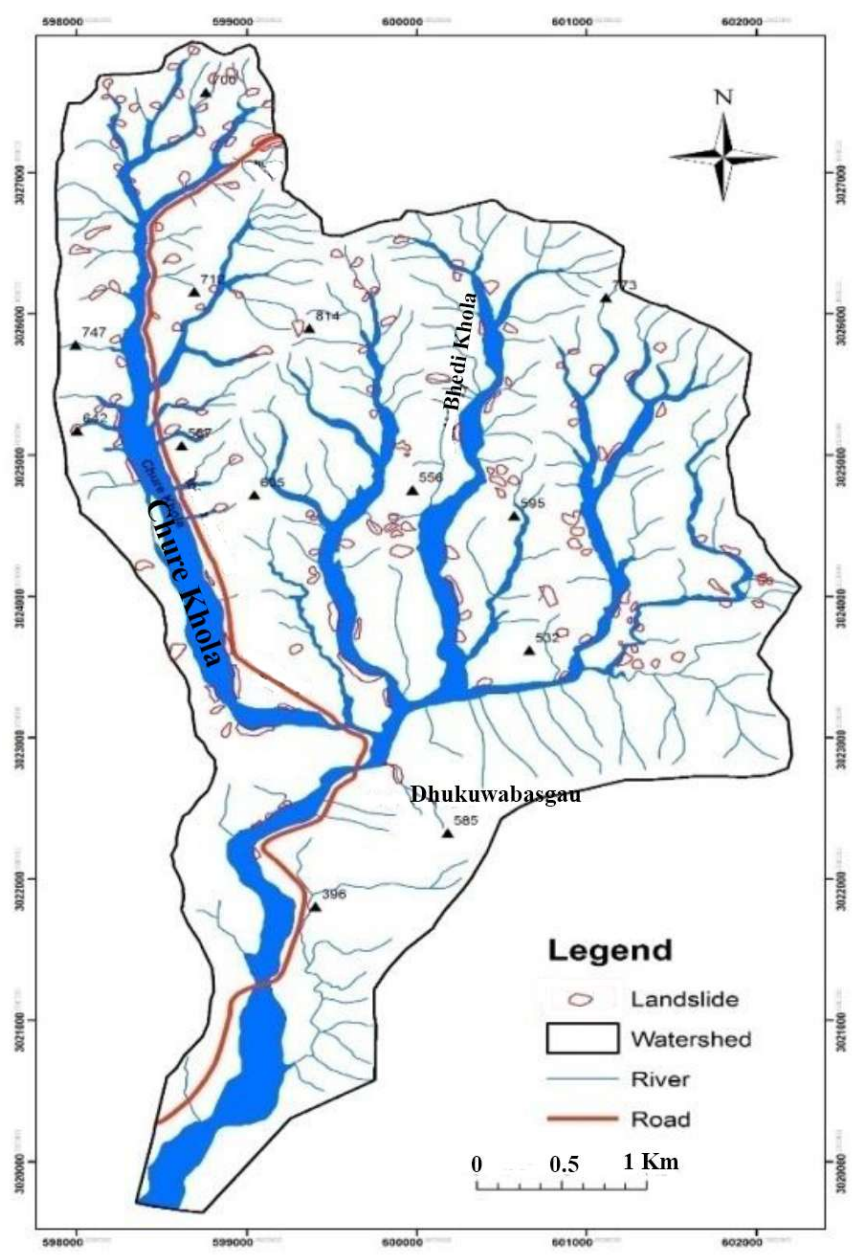

Fig. 5: Landslide Inventory Map
Causative factors are those parameters, which have the role for the stability of the slope. Some of them are favorable for the landslides triggering and some of them are unfavorable. Seven thematic maps for factors considered in the analysis: slope angle, slope aspect, elevation, drainage density, lithology (Fig. 6), curvature and river proximity, were extracted from the constructed spatial database. Bivariate analysis method uses the landslide densities within each parameter map and its classes to derived weight value for those classes (Table 4). It is based on the assumption that causative factors of landslides can be quantified by calculating landslides densities to each class.

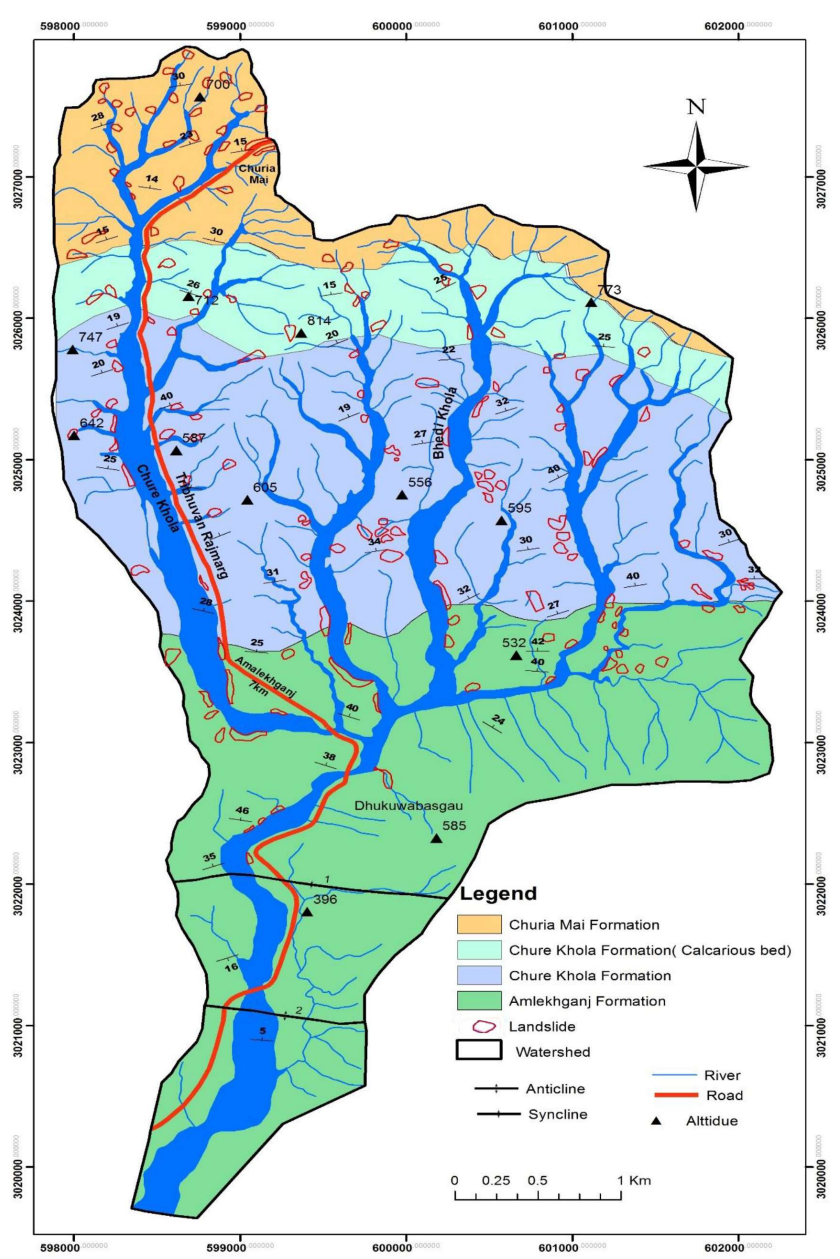

Fig. 6: Lithological Map 
Table 4: Summary of weight for various parameters

\begin{tabular}{|c|c|c|c|c|}
\hline S. N. & Parameters/Class & $\begin{array}{l}\text { Dense map } \\
\text { (Aij/A) \% }\end{array}$ & $\begin{array}{c}\text { Dense class } \\
\left(\mathrm{Aij} * / \mathbf{A}^{*}\right)\end{array}$ & Weight $\left[\ln \left\{\left(\mathrm{Aij}^{*} / \mathbf{A}^{*}\right) /(\mathrm{Aij} / \mathrm{A})\right.\right.$ \\
\hline & Geology & & & 0.0793 \\
\hline 1 & Churiya Mai Formation & 14.20 & 18.12 & 0.24419 \\
\hline 2 & $\begin{array}{l}\text { Chure Khola Formation } \\
\text { (Calcarious Beds) }\end{array}$ & 10.08 & 11.00 & 0.08728 \\
\hline 3 & $\begin{array}{l}\text { Chure Khola Formation } \\
\text { (Siliciclastic Beds) }\end{array}$ & 34.64 & 47.68 & 0.31943 \\
\hline \multirow[t]{2}{*}{4} & Amlekhganj Formation & 41.08 & 23.19 & -0.57159 \\
\hline & Elevation (m) & & & -2.34264 \\
\hline 1 & $300-400$ & 9.79 & 0.86 & -2.42849 \\
\hline 2 & $400-500$ & 22.96 & 27.94 & 0.19628 \\
\hline 3 & $500-600$ & 33.62 & 37.97 & 0.12160 \\
\hline 4 & $600-700$ & 22.99 & 25.67 & 0.11024 \\
\hline \multirow[t]{2}{*}{5} & $700-800$ & 10.63 & 7.55 & -0.34227 \\
\hline & Slope & & & 2.9697 \\
\hline 1 & $0-7^{\circ}$ & 26.48 & 22.25 & -0.17418 \\
\hline 2 & $7-15^{\circ}$ & 22.32 & 19.48 & -0.13606 \\
\hline 3 & $15-25^{\circ}$ & 31.70 & 30.89 & -0.02606 \\
\hline 4 & $25-35^{\circ}$ & 15.11 & 21.68 & 0.36090 \\
\hline 5 & $35-45^{\circ}$ & 3.59 & 4.56 & 0.24090 \\
\hline 6 & $45-60^{\circ}$ & 0.78 & 0.98 & 0.22103 \\
\hline \multirow[t]{2}{*}{7} & $60-90^{\circ}$ & 0.01 & 0.16 & 2.48322 \\
\hline & Aspect & & & -2.03145 \\
\hline 1 & Flat & 8.71 & 3.99 & -0.78029 \\
\hline 2 & North & 2.82 & 1.40 & -0.70033 \\
\hline 3 & North-East & 5.89 & 10.36 & 0.56435 \\
\hline 4 & East & 9.64 & 22.22 & 0.83518 \\
\hline 5 & South-East & 14.84 & 18.77 & 0.23500 \\
\hline 6 & South & 13.79 & 11.11 & -0.21598 \\
\hline 7 & South-West & 16.22 & 13.16 & -0.20892 \\
\hline 8 & West & 13.97 & 13.05 & -0.06791 \\
\hline 9 & North-West & 10.06 & 4.10 & -0.89743 \\
\hline \multirow[t]{2}{*}{10} & North & 4.06 & 1.83 & -0.79511 \\
\hline & Curvature & & & -0.25013 \\
\hline 1 & Concave & 10.50 & 17.48 & 0.50906 \\
\hline 2 & Straight & 77.78 & 72.17 & -0.35523 \\
\hline \multirow[t]{2}{*}{3} & Convex & 11.72 & 10.36 & -0.40396 \\
\hline & Drainage Density & & & -0.17816 \\
\hline 1 & Low & 57.70 & 71.41 & 0.21323 \\
\hline \multirow[t]{2}{*}{3} & High & 42.30 & 28.60 & -0.39138 \\
\hline & River Proximity & & & 1.79303 \\
\hline 1 & $0-10$ & 14.39 & 10.57 & -0.30821 \\
\hline 2 & $10-20$ & 3.32 & 15.43 & 1.53740 \\
\hline 3 & $20-50$ & 9.62 & 30.74 & 1.16161 \\
\hline 4 & $50-100$ & 14.54 & 19.96 & 0.31642 \\
\hline 5 & $>100$ & 58.13 & 23.30 & -0.91419 \\
\hline
\end{tabular}

These weighted parameter maps were then combined to produce landslide susceptibility map. The resultant landslide susceptible index Map (Fig. 7) has landslide susceptibility index (LSI) value varying from 7 to 30 . The LSI map should be classified into susceptibility zones to facilitate assessment of hazards.
The LSI was classified according to natural break method. The landslide susceptibility zonation map (Fig. 8) shows that $4.16 \%$ areas lie in very low, $3.6 \%$ areas in low, $11.77 \%$ in moderate, $25.28 \%$ in high and $47.18 \%$ lie in very high susceptibility zones. The areal relationship of susceptibility 


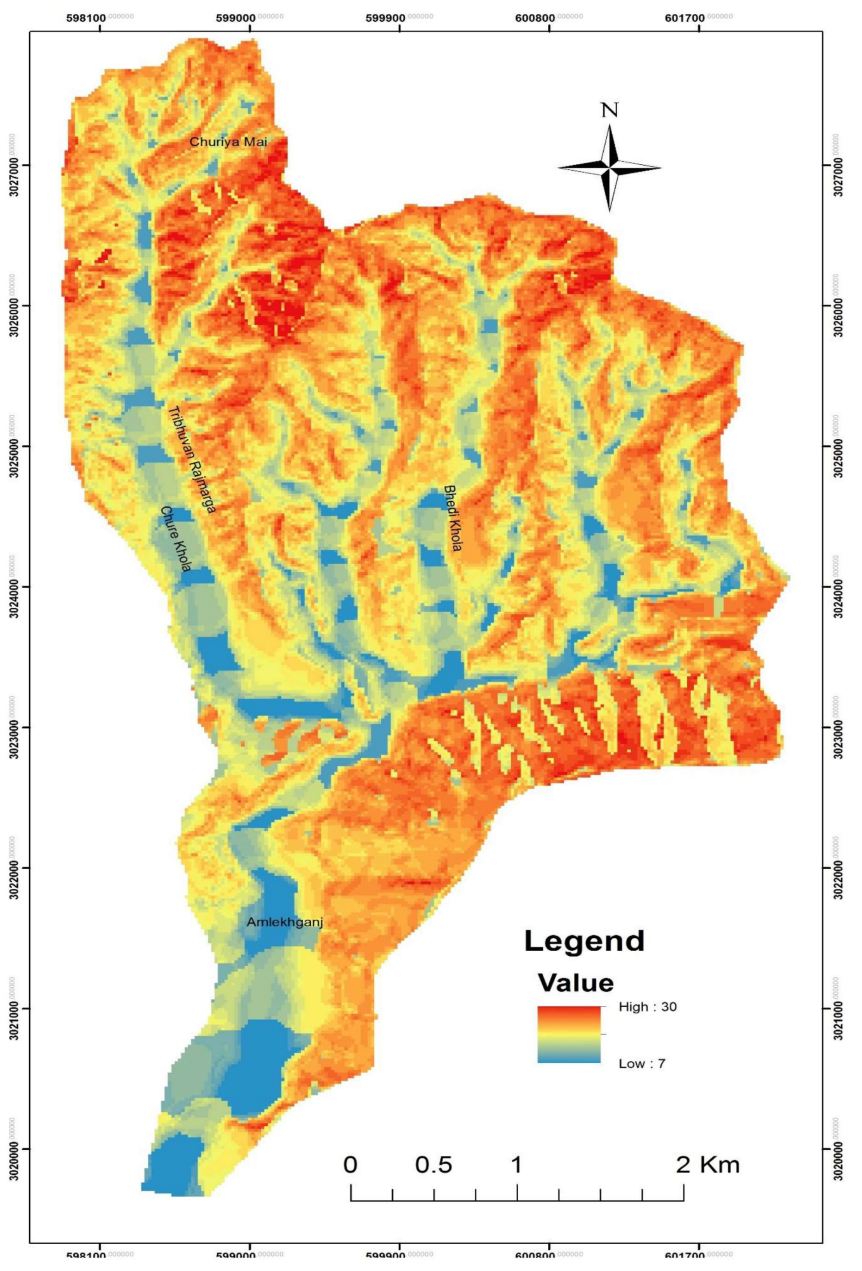

Fig. 7: Landslide Susceptibility Index Map

zones with their landslide occurrence has been tabulated (Table 5). Among the $20 \%$ separated for validation, $4.32 \%$ lie in low susceptible, $6.35 \%$ in moderate susceptible, $38.49 \%$ in high susceptible and $56.49 \%$ in very high susceptible class.

For the validation of susceptibility map, a success rate curve that indicates the suitability of map was prepared by

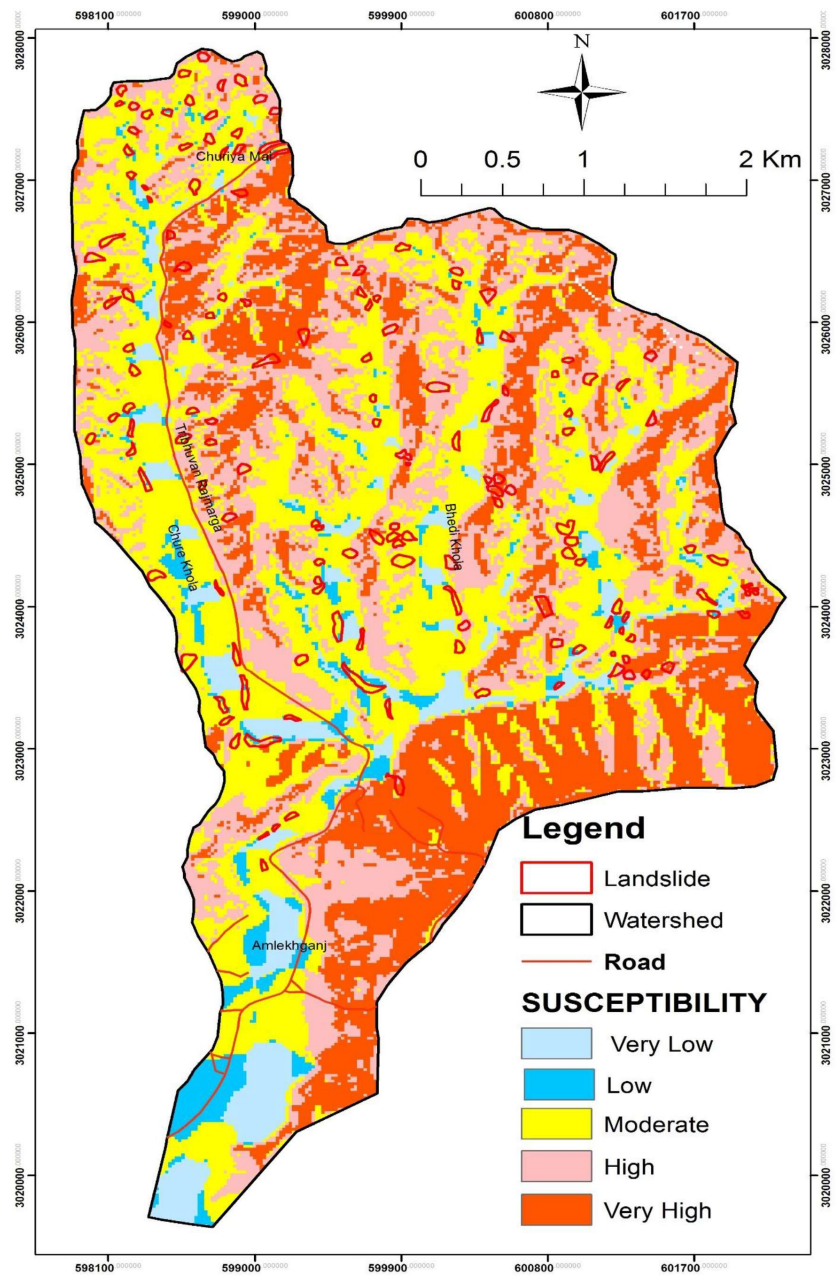

Fig. 8: Landslide Susceptibility Zonation Map

plotting the cumulative percentage of landslide to the cumulative percentage of susceptibility index value (Fig. 9). The area under curve was calculated by using the Riemann Sums method. The success rate curve shows $78.0434 \%$ of the areas lie under the curve.

Table 5: the areal relationship of the susceptibility zone with study area and training sample

\begin{tabular}{cccc}
\hline S.N. & Susceptibility & $\begin{array}{c}\text { \% landslide in each class with total } \\
\text { validating landslides }\end{array}$ & $\begin{array}{c}\text { \% Area of susceptible class with } \\
\text { total area }\end{array}$ \\
\hline 1 & Very Low (7-9) & 0 & 4.16 \\
2 & Low (9-12) & 4.32 & 3.60 \\
3 & Moderate (12-16) & 6.35 & 19.77 \\
4 & High (16-20) & 38.49 & 30.28 \\
5 & Very High (20-30) & 56.49 & 42.18 \\
\hline
\end{tabular}




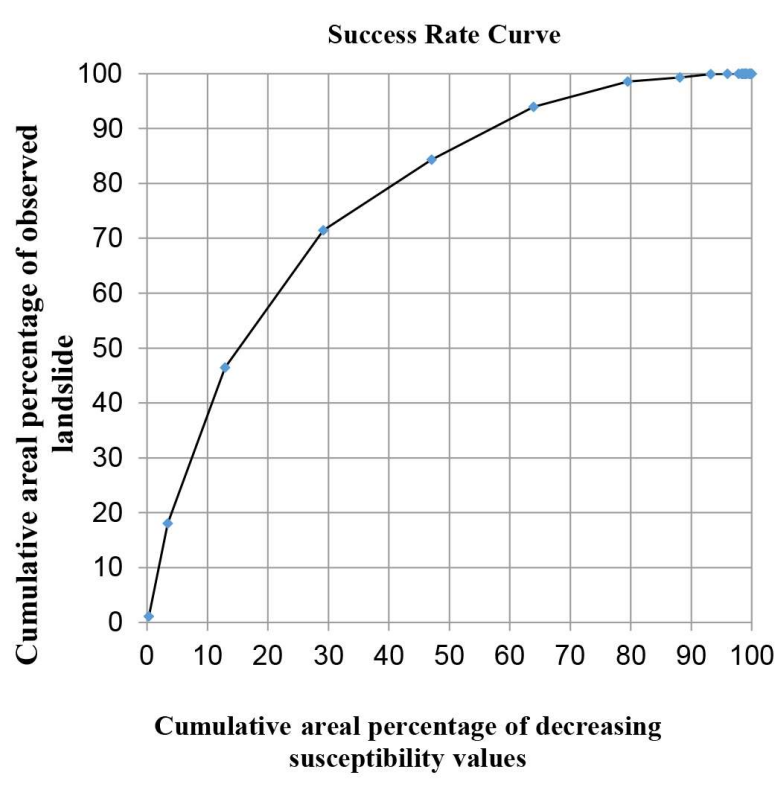

Fig. 9: Validation landslide susceptibility mapping using Success Rate Curve

\section{CONCLUSIONS}

The field-based susceptibility mapping yields (i) stable, (ii) marginally stable, (iii) susceptible and (iv) highly susceptible zones. Among the 4.179 sq. $\mathrm{km}$ area, $38.95 \%$ lie in stable zone, $17.37 \%$ in marginally stable, $22.11 \%$ in susceptible and $21.56 \%$ in highly susceptible zone. Seventy one percent of the survey sites lie in the highly susceptible zone and have recent failure. The slope material deformation condition plays important role for slope instability.

Altogether 152 landslides were observed in the study area. Factor effects reveal that all factors have relatively positive influence on the resulting landslide susceptibility map but the most effective factors on analysis are: river proximity (1.793), slope (2.970), and lithology. Landslide susceptibility zonation mapping using the Bivariate Statistical Index method yields five susceptible zones. Among the 23.52 square $\mathrm{km}$ area, 4.16 $\%$ area lie in the very low, $3.6 \%$ lie in the low, $19.77 \%$ lie in the moderate, $30.28 \%$ lie in the high and $42.18 \%$ lie in the very highly susceptibility zone. Twenty percent landslides were separated for validation. Among the $25 \%$ landslides, which were separated for validation, $87 \%$ landslides lie in moderate to very high susceptibility zones. The Success Rate Curve shows that the $78.04 \%$ area lies under the curve. The majority of the areas that lie in moderate to very high susceptibility zones due to their proximity to the river and weak lithology, should be protected and preserved applying not only the light vegetation which intercepts direct rainfall impact quite effectively but also managing the watershed drainage applying bio-engineering techniques.

\section{ACKNOWLEDGEMENTS}

This paper is based on first author's dissertation in M. Sc. Degree. Authors are thankful to CDG for providing necessary facilities. Authors are also thankful to two anonymous reviewers of this paper.

\section{REFERENCES}

Crozier, M.J. and Glade, T., 2005, Landslide Hazard and Risk: Issues, Concepts and Approach. In: Landslide hazard and risk, Glade. T., Anderson. M., and Crozier, M., Chichester, Wiley, pp. 1-40.

Crozier, M.J., 1986, Landslides: causes, consequences and environment. Croom Heim, London, 252 p.

Dahal, R.K., Hasegawa, S., Nonomura, A., Yamanaka, M., Dakal, S., and Paudyal, P., 2008, Predictive modelling of rainfallinduced landslide hazard in the Lesser Himalaya of Nepal based on weights of evidence. Geomorphology, v. 102, pp. 496-510.

Dangol, V. and Ulak, P.D., 2002, Landslide hazard mapping in Nepal: case studies from Lothar Khola (Central Nepal) and Syanja district (Western Nepal). Journal of Nepal Geological Society, v. 26, pp. 99-108.

Dhakal, A.S., Amada, T., and Aniya, M., 1999, Landslide hazard mapping and application of GSI in the Kulekhani watershed Nepal. Mountain Research and Development, v. 19(1), pp. $3-16$.

Dhital, M.R., Shrestha, R., Ghimire, M., Shrestha, G. B., and Tripathi, D., 2005, Hydrological hazard mapping in Rupandehi District, West Nepal. Journal of Nepal Geological Society, v.31, pp. 59-66.

Gerrard, J. and Gardner, R., 2002, Relationships between landsliding and land use in the Likhu Khola drainage basin, Middle Hills, Nepal. Mountain Research and Development v. 22(1), pp. $48-55$.

Hasegawa, S., Dahal, R.K., Yamanaka, M., Bhandary, N.P., Yatabe, R. and Inagaki, H. 2009, Causes of large-scale landslides in the Lesser Himalaya of central Nepal. Environmental Geology, v. 57, pp. 1423-1434.

Lee, S. and Evangelista, D.G., 2006, Earthquake induced landslide susceptibility mapping using an artificial neural network. Natural Hazards and Earth system science, v. 6, pp. 687-695.

Peckley, D.C. and Bagtang, E.T., 2010, Rain Induced landslide Susceptibility: A Guide Book for Community and NonExperts. 90p.

Sah, R.B., Ulak, P.D., Gajurel, A.P., and Rimal, L.N., 1994, Lithistratigraphy of the Siwalik Sediment of AmlekhganjHetauda area, Sub Himalaya of Nepal. Himalayan Geology, v. 15 , pp. $37-48$. 
Sikrikar, S.M., Rimal, L.N., and Jager, S., 1998, Landslide hazard mapping of Phewa Lake catchment area, Pokhara, Central West Nepal. Journal of Nepal Geological Society, v. 18, pp. 335-341.

Tamrakar, N.K., Yokota, S., and Osaka, O., 2002, A toppled structure with sliding in the Siwalik Hills, Mid-western Nepal. Engineering Geology, v. 64, pp. 339-350.

Tamrakar, N.K. and Yokota, S., 2008, Types and processes of slope movements along East-West Highway, Surai Khola area, Mid-Western Nepal Sub-Himalaya. Bull. Dept. Geol., Tribhuvan University, Kathmandu, Nepal. V. 11, pp. 1-4.

Van Westen, C., 1997, Statistical landslide hazard analysis. ILWIS 2.1 for Window application guide. ITC Publication, Enschede, pp. 73-84.

Varnes, D.J., 1978, Slope movements, types and processes. In: Schuster, R.L., Krizek, R.J. (eds), Landslide analysis and control, National Academy Sciences, Washington DC, pp.11-33. 